\title{
THE PERCEPTION OF LOW-SALT BREAD AMONG PRESCHOOL CHILDREN AND THE ROLE OF EDUCATIONAL PERSONNEL IN CREATING A POSITIVE ATTITUDE TOWARDS REFORMULATED FOOD PERCEPCIJA MANJ SLANEGA KRUHA PRI PREDŠOLSKIH OTROCIH IN VLOGA VZGOJNEGA OSEBJA PRI KREIRANJU ODNOSA DO PREOBLIKOVANEGA ŽIVILA
}

\author{
Boris KOVAC ${ }^{1 *}$, MAJA KNIFIC ${ }^{2}$ \\ 'University of Primorska, Faculty of Health Sciences, Polje 42, 6310 Izola, Slovenia \\ ${ }^{2}$ Vrtec Koper, Kettejeva ulica 13, 6000 Koper, Slovenia
}

Received: Mar 10, 2016

Original scientific article

Accepted: Jul 7, 2016

\section{ABSTRACT \\ Keywords: preschool children, hedonic sensory evaluation, salt reduction}

\section{IZVLEČEK}

Ključne besede: predšolski otroci, hedonska ocena, zmanjševanje slanosti
Introduction. The purpose of this study was to identify the possibility of unnoticed reduction in salt content of bread as a basic food in the diet of preschool children. The response of children to less salty bread and the role of teachers and teacher assistants in the introduction of novelties into children's nutrition ware studied.

Methods. Using hedonic sensory evaluation in the case of bread, the perception of salty taste and responses of preschool children to salt reduction were observed. The combination of quantitative and qualitative data analysis obtained from the case study group, composed of 22 preschool children and 66 teachers and teacher assistants, was studied.

Results. The results show that a $30 \%$ salt reduction was not registered by the children, while a $50 \%$ reduction of the salt content, compared to the original recipe, though noted, was not disruptive. The perception of taste and development of good eating habits at an early age could be influenced by teachers and teacher assistants' verbal and non-verbal communication.

Conclusion. Salt reduction does not significantly affect the rating of satisfaction with the tested product. Educational personnel must be aware of their decisive influence on children's perception of new and less salty products. Such an approach could represent a basis for creating children's eating habits, which will be of particular importance later in their lives. The findings may possibly result in an update of the national nutrition policy.

Namen. Namen raziskave je bil opredeliti možnost neopaznega zmanjšanja vnosa soli s kruhom kot osnovnim živilom $v$ prehrani predšolskih otrok. S študijo smo želeli ugotoviti odzive otrok na manj slan kruh in opredeliti vlogo vzgojnega osebja pri otrokovem sprejemanju prehranskih novosti.

Metode. Na primeru kruha smo s pomočjo hedonskega ocenjevanja raziskovali zaznavanje slanega okusa ter odzive predšolskih otrok na zmanjšanje slanosti. V raziskavi smo uporabili kombinacijo kvantitativne in kvalitativne analize podatkov, pridobljenih s študijo primera skupine, ki je štela 22 predšolskih otrok in 66 članov vzgojnega osebja. S pomočjo vprašalnika odprtega tipa smo proučevali opažanje vzgojnega osebja o vplivu vrstnikov ter verbalnega in neverbalnega sporočanja vzgojnega osebja na otrokovo sprejemanje novega prehranskega izdelka.

Rezultati. Otrokom smo ponudili kruh običajne slanosti ter kruh s 30- in 50-odstotno zmanjšano vsebnostjo soli glede na izvorno recepturo. Rezultati so pokazali, da otroci zmanjšanja okusa slanosti za $30 \%$, torej na $70 \%$ izhodiščne vrednosti, večinoma ne zaznajo. Zmanjšanje slanosti na $50 \%$ so otroci zaznali, vendar so ponujene različne vrste kruha kljub spremenjenemu okusu dobro sprejeli in niso nobenega vzorca ocenili kot nesprejemljivega. Iz rezultatov ankete vzgojnega osebja lahko zaključimo, da osebje lahko moderira izražanje vrstnikov v skupini do določenega živila ter s svojo verbalno in neverbalno komunikacijo vpliva na oblikovanje dobrih prehranskih navad v zgodnjem otroštvu.

Zaključek. Manj slan kruh je bil dobro sprejet, zmanjšanja slanosti otroci večinoma niso zaznali, razlike $v$ ocenah niso statistično značilne. Vzgojno osebje se mora zavedati svojega odločilnega vpliva na otrokovo percepcijo novih in manj slanih izdelkov. Tak pristop $k$ zmanjševanju vnosa soli bi lahko bil osnova za oblikovanje prehranskih navad otrok, ki so še zlasti pomembne v poznejših starostnih obdobjih. Ugotovitve bi lahko pripomogle $k$ nadgradnji nacionalne prehranske politike. 


\section{INTRODUCTION}

A carefully chosen diet along with physical activity is one of the key factors affecting children's health and well-being. Children's eating habits are established in the preschool period. This process is affected through family eating habits as well as preschool nutrition in kindergartens, where children usually spend most of their days and consume most of their daily meals. The concern for the quality of food and eating habits in preschool is therefore extremely important for the development and formation of eating habits later in life. Children learn about food through the direct experience of eating and by observing the eating behaviours of others. Children's eating patterns develop during early social interactions (1). When children go outside their familiar environments, they are influenced by adults and other role models, such as educational personnel in kindergartens.

When planning meals for children and youth in preschools, schools and other educational care centres, guidelines (2) which provide recommendations for creating menus for children from the age of one are followed. Practical examples are also presented in healthy eating menus provided under the heading Practice (3). When developing children's eating habits, we must take into account different factors, such as children's age, geographical locations of the places where they live, and the resulting characteristics of nutrition, eating habits from the immediate environment (family) and children's wider environment (preschool, school). Finally, children's diet is also influenced by religious principles and dietary restrictions due to health problems.

The legal basis for the provision of adequate healthy food is defined in legislation. The ordering of food for adequate meals in public institutions is determined by a public procurement procedure, a part of which focuses on organic and local products (4). The development of appropriate dietary habits in early childhood represents an investment in behaviour during adolescence and adulthood. Appropriate consumption patterns and physical activity prevent chronic non-communicable diseases; therefore, the system of mass caterers has to aim for the creation of positive approaches to a healthy life.

A large proportion of salt is frequently consumed by eating bread as a staple food. This is the reason why the public health policy focuses on bread as a means of salt intake reduction in the daily diet. The excessive intake of salt as a public health problem is mentioned in the context of preventing chronic non-communicable diseases, mainly cardiovascular diseases. The excessive intake of sodium is a risk factor for hypertension, which is also a cause of cardiovascular diseases and stroke. Studies also suggest a link between excessive salt intake and gastric cancer, osteoporosis, asthma, kidney stones and type 2 diabetes (5).
The experience of countries that have introduced systematic salt intake reduction in the population's diet shows that a systematic and gradual reduction of the consumption of salt is needed. Cooperation with the food processing industry and mass catering providers must also be established, with awareness-raising activities for the population carried out simultaneously (5). According to World Health Organization (WHO) guidelines, the population of Slovenia exceeds the maximum recommended daily salt intake in their diets adults by $150 \%$, adolescents by $100 \%$ and children by $67 \%$. WHO guidelines are already exceeded when consuming between $5-6 \mathrm{~g}$ of salt per day in staple foods $(5,6)$.

The National Institute of Public Health of the Republic of Slovenia carried out a national survey in 2005 and 2007, on the salt content of bread and bakery products, which was repeated in 2009/10. Samples of large producers of bread from Slovenia were analysed with the research showing that the samples contained excessive amounts of the recommended target values of salt content. Whereas white, mixed, brown, rye and wholemeal bread contained an average salt content of $1.4 \mathrm{~g} / 100 \mathrm{~g}$, semi-white bread contained $1.2 \mathrm{~g} / 100 \mathrm{~g}$ of salt content (7).

In 2012, the WHO published guidelines on sodium intake for adults and children. In Slovenia, the National Action Plan on reduced salt intake in the diet of people in Slovenia, for the period 2010-2020, provides recommendations regarding the consumption of sodium (7). The following recommendations were set by the WHO: a reduction in sodium intake to reduce blood pressure and risk of cardiovascular disease, stroke and coronary heart disease in adults to less than $2 \mathrm{~g} /$ day, which represents $5 \mathrm{~g}$ salt/ day. For children, the value is adjusted according to the energy requirements of children relative to those of adults (8).

Scholars mention several different approaches to daily salt intake reductions. One of the approaches is 'gradual reduction without the consumer's knowledge', which refers to the observation that people in general are unable to determine the differences between two substances in which the difference in salt content is about $10 \%$ (described as 'Just Noticeable'). However, the ratio of the concentration not perceptible to the consumer is different for different foods or different preparation techniques. A $25 \%$ reduction of salt intake in bread without affecting the participants' perception was reported (9), but with the remark that all manufacturers should change the preparation technology.

Due to genetic predisposition, people prefer sweet and salty tastes. This preference is an unlearned, reflexive reaction. The majority of children prefer high-energydense foods to low-energy-dense ones. Infants (under 4 months) showed neither a favourable nor a dismissive attitude towards saltiness. However, infants at the age of 
4 months start expressing a preference for salty tastes. In early childhood, the preference intensifies, so that children prefer saltiness more than adults, a pattern that is comparable to the sweet preference. Furthermore, the degree of salt concentration that children develop in childhood determines the level of preferred salt concentration in adulthood (1).

Whether a food is liked or disliked is an important determinant of food intake, especially among children. Salt contributes to the taste of foods and makes them more enjoyable (10). Salt level generally has a positive impact on the intake of the target foods $(11,12)$. Research found that 4-month-old infants identified and selected salted and not plain water, which indicates their salt taste perception mechanism, and 6-month-old infants who were fed salty starchy table food retained their tendency towards salty foods later in childhood (13). Results of the research showed that children aged 4 or more prefer salty foods to unsalted ones.

Various studies have shown that after consuming food with reduced salt content for a certain period of time (up to twelve weeks), the preferred level of salt in food is lowered to such a level that foods with high salt content become unpleasant for the subjects (14). Results of a recent research provide the evidence that promoting responsive feeding practices can alter the development of eating behaviour, sleep patterns and early self-regulatory skills, as well as reduce early obesity risk (15).

Studies also confirm that salt taste preference is formed in early childhood. Early experiences also affect food behaviour later in life, which should be considered when planning salt reduction initiatives $(16,17)$.

The aim of the research was to determine how children respond to the new less salty taste of bread and how they adopt it. The survey among educational personnel was carried out to define the role of teachers and teacher assistants in introducing novelties into children's nutrition. The aim was to explore educational personnel's opinions regarding their own influence and peer influences on children's perception of a food product.

\section{MATERIALS AND METHODS}

The survey was divided into phases. In the first phase, children and educational personnel evaluated different types of bread - rye, white, semi-white, brown, whole grain and oat bread, prepared with standard salt contents. The salt content in the final product was $1.4 \mathrm{~g}$ of $\mathrm{NaCl} / 100$ $\mathrm{g}$, which is the amount that is contained in the commercial bread on the Slovenian market. The salt content of the bread was reduced by $70 \%$ and $50 \%$ compared to the standard bread, and it was tested using the same procedure. The bread samples were baked in the local bakery Mlinotest Kruh Koper. The bread was prepared by slicing it into $1 \mathrm{~cm}$ wide pieces 8 hours after baking. One bread sample per day was evaluated. The ratio of volume/ weight determined the structure of bread. Oat, brown and rye bread had a compact structure, while white, semi white and wholegrain bread had a soft structure. Children were given an additional piece of bread to eat before their regular meal, which consisted of the usual bread with cheese spread. They were encouraged to pay attention to the taste, smell, texture, and to remember their feelings while eating the bread. After the meal, children evaluated their opinions regarding the bread by using an emotional facial expression.

\section{1 Subjects}

Preschool children were recruited from the kindergarten Vrtec Koper, located in the town of Koper. A group of 22 children aged between 4 and 5 years, and 66 teachers and teacher assistants of all age groups of children aged between 1 and 5 years participated in the research. The study was performed between February and June 2015. The average length of service of educational personnel was 16.6 years, with $73 \%$ of the teachers and assistants possessing more than 5 years of experience in working with children.

\subsection{Methods}

The survey method was adapted to the age of the children. We took into account that sensory or consumer tests for children should respect the range of sensory and cognitive abilities of children. As described in previous studies (18), the hedonic assessment method using three emotional facial expressions is suitable for children at this age. The method applied is described by Chen et al. (19). A scale of hedonic evaluation was used to interview the children using the images of three emotional facial expressions: a smiling face (:) - 'tasty, I like it'; indifferent face $:-$ - 'acceptable, I do not like it a lot, but it is still quite good'; sad face $: 2$ - 'less tasty, I do not like it'. A mixed questionnaire with open-ended and closed-ended questions was prepared for the survey to be given out to educational personnel. Closed-ended questions are shown in Tables 3 and 4. Two open-ended questions were given to educational personnel. Open-ended questions were answered with a descriptive response, with which teachers had to state their observations and opinions regarding their own and peers' role in the creation of children's eating habits.

\subsection{Data Analyses}

Statistical analysis of the results was evaluated using the Fisher exact probability test. It yields a probability value $p$, defined as the probability of the observed array of cell frequencies, plus the sum of the probabilities 
of all other cell-frequency arrays that are smaller than the probability of the observed array. We considered statistically significant the results with $\mathrm{p}$-value $<0.05$.

\section{RESULTS}

In the first part of the survey, the participants evaluated bread with standard salt content, which is also included on the regular children's menu, while the educational personnel evaluated breads with standard salt content in the same way as the children; the results are shown in Table 1.

Table 1. Hedonic evaluation of bread with normal salt content by children and educational personnel.

\begin{tabular}{|c|c|c|c|c|c|c|c|c|}
\hline \multirow{2}{*}{\multicolumn{2}{|c|}{$\begin{array}{l}\text { TYPES OF BREAD } \\
100 \% \text { salt content }\end{array}$}} & \multicolumn{2}{|c|}{;) } & \multicolumn{2}{|c|}{ : } & \multicolumn{2}{|c|}{$:$} & \multirow{2}{*}{$\mathrm{p}$-value } \\
\hline & & $\mathrm{n}$ & $\%$ & $\mathrm{n}$ & $\%$ & $\mathrm{n}$ & $\%$ & \\
\hline \multirow[t]{2}{*}{ wholegrain } & children & 15 & 100.0 & 0 & 0.0 & 0 & 0.0 & 0.2776 \\
\hline & personnel & 54 & 81.8 & 11 & 16.7 & 1 & 1.5 & \\
\hline \multirow[t]{2}{*}{ white } & children & 15 & 100.0 & 0 & 0.0 & 0 & 0.0 & 0.0270 \\
\hline & personnel & 45 & 68.2 & 14 & 21.2 & 7 & 10.6 & \\
\hline \multirow[t]{2}{*}{ semi-white } & children & 14 & 93.3 & 1 & 6.7 & 0 & 0.0 & 0.1918 \\
\hline & personnel & 45 & 68.2 & 17 & 25.8 & 4 & 6.1 & \\
\hline \multirow[t]{2}{*}{ oat } & children & 13 & 76.5 & 4 & 23.5 & 0 & 0.0 & 0.7250 \\
\hline & personnel & 43 & 65.2 & 21 & 31.8 & 2 & 3.0 & \\
\hline \multirow[t]{2}{*}{ rye } & children & 13 & 86.7 & 2 & 13.3 & 0 & 0.0 & 0.5571 \\
\hline & personnel & 46 & 69.7 & 18 & 27.3 & 2 & 3.0 & \\
\hline \multirow[t]{2}{*}{ brown } & children & 13 & 86.7 & 2 & 13.3 & 0 & 0.0 & 0.2772 \\
\hline & personnel & 42 & 63.6 & 21 & 31.8 & 3 & 4.5 & \\
\hline
\end{tabular}

More than $60 \%$ of the children evaluated all the bread types as tasty. Not many of the bread types were evaluated as acceptable, with semi-bread evaluated as acceptable only once, while wholegrain and white bread did not receive any less tasty assessments. None of the bread types was evaluated by children as less tasty. The results show that the educational personnel prefer bread with a definite taste (oat, brown), compact structure (rye) and semi-white bread. The differences among children and personnel are not statistically significant except with regard to white bread. The educational personnel did not perceive white bread to be as tasty as children did, which indicates a p-value which is below 0.05 , the reason being that the educational personnel felt that the white bread compared to other types, had a less definite taste, while white bread has a soft structure which children like. In the second part of the survey, children were presented with bread which had a $70 \%$ and $50 \%$ lower salt content compared to the standard recipe. The results are shown in Table 2. Satisfaction with bread, despite the reduced salt content, is high and comparable with standard salty bread. 
Table 2. Hedonic evaluation of different types of bread and salt content by children.

\begin{tabular}{|c|c|c|c|c|c|c|c|c|}
\hline \multirow{2}{*}{ TYPES OF BREAD } & \multirow{2}{*}{$\begin{array}{l}\text { Salt } \\
\text { content }\end{array}$} & \multicolumn{2}{|c|}{ (:) } & \multicolumn{2}{|c|}{$\dot{\theta}$} & \multicolumn{2}{|c|}{ : } & \multirow[t]{2}{*}{$\mathrm{p}$-value } \\
\hline & & $\mathrm{n}$ & $\%$ & $\mathrm{n}$ & $\%$ & $\mathrm{n}$ & $\%$ & \\
\hline \multirow[t]{3}{*}{ wholegrain } & 100 & 15 & 100.0 & 0 & 0.0 & 0 & 0.0 & 0.1060 \\
\hline & 70 & 15 & 100.0 & 0 & 0.0 & 0 & 0.0 & \\
\hline & 50 & 13 & 86.7 & 2 & 13.3 & 0 & 0.0 & \\
\hline \multirow[t]{3}{*}{ white } & 100 & 15 & 100.0 & 0 & 0.0 & 0 & 0.0 & 0.6442 \\
\hline & 70 & 14 & 93.3 & 1 & 6.7 & 0 & 0.0 & \\
\hline & 50 & 14 & 87.5 & 2 & 12.5 & 0 & 0.0 & \\
\hline \multirow[t]{3}{*}{ semi-white } & 100 & 14 & 93.3 & 1 & 6.7 & 0 & 0.0 & 0.8370 \\
\hline & 70 & 14 & 87.5 & 2 & 12.5 & 0 & 0.0 & \\
\hline & 50 & 9 & 81.8 & 2 & 18.2 & 0 & 0.0 & \\
\hline \multirow[t]{3}{*}{ oat } & 100 & 13 & 76.5 & 4 & 23.5 & 0 & 0.0 & 0.8982 \\
\hline & 70 & 12 & 85.7 & 2 & 14.3 & 0 & 0.0 & \\
\hline & 50 & 13 & 81.3 & 3 & 18.8 & 0 & 0.0 & \\
\hline \multirow[t]{3}{*}{ rye } & 100 & 13 & 86.7 & 2 & 13.3 & 0 & 0.0 & 0.7944 \\
\hline & 70 & 12 & 80.0 & 3 & 20.0 & 0 & 0.0 & \\
\hline & 50 & 10 & 76.9 & 3 & 23.1 & 0 & 0.0 & \\
\hline \multirow[t]{3}{*}{ brown } & 100 & 13 & 86.7 & 2 & 13.3 & 0 & 0.0 & 0.3886 \\
\hline & 70 & 12 & 80.0 & 1 & 6.7 & 2 & 13.3 & \\
\hline & 50 & 11 & 100.0 & 0 & 0.0 & 0 & 0.0 & \\
\hline
\end{tabular}

The results show that children generally did not detect salt reduction or they did not describe it as disturbing. Children who evaluated breads using an indifferent emotional facial expression did not associate those breads with the concept of 'less salty'. They just explained what they wanted to say about the bread they ate. When the salt content was $50 \%$ of the standard content, educational personnel noted that children observed a change in taste, and despite the difference in taste, evaluated breads as tasty. However, fewer types of bread were described as tasty compared to the bread with $70 \%$ salt content. The assessment of 'less tasty' was not given to any of the breads. The differences in perception of any type of bread with varied salt content were statistically non-significant.

Educational personnel spend a lot of time with children in the active part of every day. They monitor their behaviour continuously during each meal, and they observe children's reactions to food. This gives staff sufficient knowledge and experience to assess how certain characteristics of bread impact children's perception and acceptability of a particular product. Table 3 shows observations of educational personnel regarding the importance of some specific characteristics of bread.
Table 3. Observations of educational personnel regarding the importance of specific characteristics for children's acceptance of bread.

\begin{tabular}{|c|c|c|c|c|}
\hline & \multicolumn{2}{|c|}{ important } & \multicolumn{2}{|c|}{ less important } \\
\hline & $n$ & $\%$ & $\mathrm{n}$ & $\%$ \\
\hline taste & 65 & 98.5 & 1 & 1.5 \\
\hline appearance & 60 & 90.9 & 6 & 9.1 \\
\hline colour & 55 & 83.3 & 11 & 16.7 \\
\hline smell & 43 & 65.2 & 23 & 34.8 \\
\hline texture & 41 & 62.1 & 25 & 37.9 \\
\hline
\end{tabular}

The results show that three characteristics were assessed as the most important - characteristics that also form the first impression of a food product, namely taste, appearance and colour. However, bread is a very complex food from the visual and organoleptic point of view, and it is difficult to define correlations among children's answers as shown in Table 1, and observations of educational personnel as defined in Table 3. 
Children imitate each other, therefore peer influence is certainly present when children are eating or talking about food. Observations of the educational personnel regarding peer influence and the effect of verbal and nonverbal communication of the educational personnel on the children's acceptance of food products are given in Table 4. Two open-end questions were posed - the first to evaluate peer influence and the second to evaluate the effect of educational personnel's verbal and nonverbal communication on children's acceptance of food products. Qualitative answers are shown in the table below.

Table 4. Observations of educational personnel regarding peer influence, and the effect of verbal and nonverbal communication of educational personnel on children's acceptance of food products.

\begin{tabular}{lcc}
\hline & $\mathbf{n}$ & $\%$ \\
\hline Peer influence & & \\
strong influence & 42 & 63.6 \\
mild influence & 15 & 22.7 \\
no influence & 9 & 13.6 \\
Educational personnel influence & & \\
strong influence & 52 & 78.8 \\
mild influence & 8 & 12.1 \\
no influence & 6 & 9.1 \\
\hline
\end{tabular}

Peer influence is important; its negative influence can be mitigated by educational personnel. Two openend questions were asked, the first one to evaluate peer influence and the second one to evaluate the effect educational personnel's verbal and nonverbal communication had on children's acceptance of food products. The teachers stated the following observations:

- $\quad$ Peer influence is less visible in toddlers;

- influence varies according to the age of children;

- children taste a meal if they see others eating it, or they reject it when other children do the same;

- children imitate each other, therefore peer influence is certainly present;

- $\quad$ children are not under so much peer influence when in a guided group. However, personnel must be careful when talking about a specific meal;

- $\quad$ educational personnel have to reduce negative peer influence and, as an example, influence children's behaviour during meals.

Educational personnel's opinions regarding the importance of their role in persuading children to accept some foods or food products show that they are aware of the educational importance of kindergarten meals. The teachers stated the following observations:
- Children can sense educational personnel's reaction to a meal only by observing their facial expressions. If the opinion is negative, it reflects in the whole group;

- $\quad$ teachers and teacher assistants are role models for children;

- verbal and non-verbal communication is very important. Educational personnel must try all the food that is offered to children and must approve it even if they do not like it;

- $\quad$ educational personnel must present food to children in an appealing way, so that they want to taste it;

- $\quad$ educational personnel's appropriate attitude to food and encouragement can help a lot, inducing children to try the food, and be proud of themselves if they are also praised;

- it is important to convince children to at least try the food/product.

The results of the closed-ended questionnaire indicate that $78 \%$ of the educational personnel attach strong importance to their educational role in eating habits. The analysis of the open-ended responses, which encompass the experience of working with children, shows that educational personnel can affect children's perception of food.

\section{DISCUSSION}

The majority of children in Slovenia (92\%) aged between 3 and 5 years attend kindergartens; however, the percentage of children aged between 1 and 5 years is lower, comprising only $77 \%$ (20). This means that children experience nutrition in both domestic and kindergarten environments. Children's responses to bread with unreduced standard salt content show they prefer white, semi-white and wholegrain bread, perhaps because of its soft structure. Brown, rye and oat bread were described as tasty (with a happy emotional facial expression); however, the percentage of breads evaluated with a lower mark was slightly higher. Preschool children primarily notice physical characteristics, such as colour, shape and structure in forming an opinion about certain foods (14). None of the children marked any of the breads as less tasty. There is no statistical difference in the evaluation of standard salted bread types between the children and educational personnel, except for white bread where the $\mathrm{p}$-value is lower than 0.05 .

We wanted to determine whether children find the bread with reduced salt content different enough to assess it as worse than the bread with normal salt content. Children were not previously told to pay attention to the saltiness of the product. They evaluated the product as a whole. Using emotional faces, they only explained what they wanted to say about the bread they were eating. Despite 
the limitations of the hedonic evaluation, the results give us a vital answer - children like bread with reduced salt content. The statistical analysis of data using the Fisher exact probability test confirmed that evaluations of low-salt bread do not show deviations from the normal ratings of the same type of bread. These findings partially correspond to the results of the study by Girgis et al. (9), which showed that a $25 \%$ salt reduction can be made without being noticed. However, the results of our study indicate that children also accept breads with only 50\% salt content, although results of some previous studies suggest that children prefer salty foods to unsalted ones (12). Children did not associate those pieces of bread with the concept of 'less salty'.

The environment children live in, in particular persons they come in contact with, is also important in formulating children's eating habits and influencing children's acceptance of specific tastes. The effectiveness of a child's role model in food preferences depends on the relationship between the child and the role model. A role model is a person who serves as an example by influencing others. For many children, the most important role models are their parents and caregivers. Children look up to different role models in order to help shape their behaviour in school, their relationships, or when making difficult decisions. Children also look up to other relatives, teachers and peers. Important role models for preschool children are older people or celebrities, and other characters that children admire. These people are more effective role models than unknown people (11). Peers in kindergarten play an important role in shaping children's eating habits. It is not uncommon for children to eat certain types of food that they initially decline at home. Children can also reject dishes simply because they are sitting next to their peers eating the meal with pleasure (21). Other surveys stress the influence of the environment outside the kindergarten; however, the results of this survey and its qualitative answers indicate that educational personnel have a significant impact on children's preference for a specific product. This influence can help reduce the salt intake in the daily diet of children and also adjust children to a lower salt diet later in life.

\section{CONCLUSIONS}

We found that salt reduction does not affect the rating of satisfaction with the offered product significantly. This was a step towards reducing salt intake in the daily diet of children, and adapting children to less salty dishes.

The environment outside the kindergarten has an important impact on children. The role of adults, parents and teachers is to help children develop healthy eating habits. We can conclude that educational personnel are aware of their important educational role in child-feeding activities, and that they have a significant influence on children's preference of a specific product.

The success of the salt reduction project at the national level definitely depends on the macro-environment. Continuous education of all people involved regarding the importance of salt intake reduction in the daily diet and its effects on human health is necessary, the most important being educational personnel on one hand, and parents on the other.

\section{CONFLICTS OF INTEREST}

The authors declare that no conflicts of interest exist.

\section{FUNDING}

This study was not financed.

\section{ETHICAL APPROVAL}

All the data analysed in this study were collected at the Vrtec Koper kindergarten, without collecting any information regarding the identity of individuals. Parents gave permission for their children's participation in the study. The study was conducted in accordance with the International Code of Medical Ethics of the World Medical Association (Declaration of Helsinki).

\section{REFERENCES}

1. Savage JS, Fisher JO, Birch LL. Parental influence on eating behavior conception to adolescence. J Law Med Ethics 2007; 35: 22-34.

2. Gabrijelčič Blenkuš $M$, Pograjc L, Gregorič $M$, Adamič $M$, Čampa A. Smernice zdravega prehranjevanja $v$ vzgojno-izobraževalnih ustanovah, Ljubljana: Ministrstvo za zdravje, 2005.

3. Hlastan Ribič C, Maučec Zakotnik J, Koroušić Seljak B, Pokorn D. Praktikum jedilnikov zdravega prehranjevanja $v$ vzgojnoizobraževalnih ustanovah. Ljubljana: Ministrstvo za zdravje, Zavod Republike Slovenije za šolstvo, 2008.

4. Ministrstvo za kmetijstvo in okolje, Ministrstvo za finance. Priporočila za javno naročanje živil. Available Feb 15, 2016 from:

5. http://www.mkgp.gov.si/fileadmin/mkgp.gov.si/pageuploads/ podrocja/Kmetijstvo/Promocija_SI_kmetijstva/priporocila_JN_zivil. pdf.

6. Hlastan Ribič C. Sol - javno zdravstveni problem. In: XX. Strokovni sestanek sekcije za hipertenzijo. Ljubljana: Slovensko zdravniško društvo, Sekcija za hipertenzijo, 2011: 862-75.

7. Hlastan Ribič C, Pokorn D, Poličnik R, Kulnik D. Prehranski vnos predšolskih otrok. Slov Pediat 2006; 13: 25-31.

8. Ministrstvo za zdravje Republike Slovenije. Nacionalni akcijski načrt za zmanjševanje soli v prehrani prebivalcev Slovenije za obdobje 2010-2020. Available Feb 15, 2016 from: www.dlib.si/stream/ URN:NBN:SI:DOC-ZF4CAGWN/531c3aOf. 
9. WHO. Guideline: sodium intake for adults and children. Geneva: World Health Organization, 2012.

10. Girgis S, Neal B, Prescott J, Prendergast J, Dumbrell S, Turner C, et al. A one-quarter reduction in the salt content of bread can be made without detection. Eur J Clin Nutr 2003; 57: 616-20.

11. Birch LL. Development of food preferences. Annu Rev Nutr 1999; 19: 41-62.

12. Bouhlal S, Issanchou S, Nicklaus S. The impact of salt, fat and sugar levels on toddler food intake. Br J Nutr 2011; 105: 645-53.

13. Beauchamp GK, Cowart BJ. Preference for high salt concentrations among children. Dev Psychol 1990; 26: 539-45.

14. Stein LJ, Cowart BJ, Beauchamp GK. The development of salty taste acceptance is related to dietary experience in human infants: a prospective study. A J Clin Nutr 2012; 95: 123-29.

15. Matheson D, Spranger K, Saxe A. Preschool children's perceptions of food and their food experiences. J Nutr Educ 2002; 34: 85-92.

16. Birch LL. Learning to eat: behavioral and psychological aspects. Nestle Nutr Inst Workshop; 2016; 85: 125-34.

17. De Simone J, Beauchamp GK, Drewnowski A, Johnson GH. Sodium in the food supply: challenges and opportunities. Nutr Rev 2013; 71: 52-9.

18. Skinner JD, Carruth BR, Wendy B, Ziegler PJ. Children's food preferences: a longitudinal analysis. J Am Diet Assoc 2002; 102: 1638-47.

19. Guinard JX. Sensory and consumer testing with children. Trends Food Sci Tech 2001; 11: 273-83.

20. Chen AW, Resurreccion AVA, Paguio LP. Age appropriate hedonic scales to measure food preferences of young children. J Sens Stud 1996; 11: 141-63.

21. Predšolska vzgoja in izobraževanje $v$ vrtcih, Slovenija, šolsko leto 2012/13 - končni podatki. Available Apr 11, 2016 from: http: //www.stat.si/StatWeb/glavnanavigacija/podatki / prikazistaronovico?ldNovice $=5386$.

22. Roberts M, Pettigrew S. Psychosocial influences on children's food consumption. Psychol Market 2013; 3: 103-20. 